\title{
ПЕРЕАТРИБУЦИЯ ОДНОЙ ИЗ МОНЕТ САЙРАМСКОГО КЛАДА 2013 г.
}

\author{
(C) 2018 г. А.О. Брагин
}

В результате целенаправленного поиска аналогов тимуридских серебряных монет, которые были встречены и изучены в Сайрамском кладе 2013 г., обнаружена возможность уточнения атрибуции одного из типов монет клада. В заметке описывается серебряная танга с сохранившимся названием монетного двора, тип которой совпадает с описанным в каталоге «Сайрамский клад тимуридских монет» под №№ 199, 200. Ранее авторами каталога эти две монеты были отнесены к монетному двору Бакуйа, но обнаруженный экземпляр позволяет изменить эту атрибуцию и отнести тангу к выпускам монетного двора Салмас.

Ключевые слова: археология, Сайрамский клад, нумизматика, XIV-XV вв., Тимуриды, амир Тимур, каталог, монетные легенды, монетный двор, танга, серебро, уточнение атрибуции

В ходе планомерной работы по изучению монетного дела и денежного обращения династии Тимуридов, был выявлен в одной из коллекций России интересный экземпляр тимуридской танга. Монета, имея неполный прочекан поля и следы обращения, все же сохранила на себе информацию о наименовании монетного двора. Чтение названия эмиссионного центра не вызвало затруднений - Салмас. Местоположение этого монетного двора локализуется в Иране, в провинции Западный Азербайджан. При последующем сравнении с описанными монетами Сайрамского клада были найдены похожие экземпляры, а именно №№ 199, 200 [Байтанаев и др., 2014, с. 47, фото на c. 559].

Составляя каталог монет Сайрамского клада [Байтанаев и др., 2014a; 2014б; 2015] на этапе группировки серебряных монет, отчеканенных в Бакуйе, авторами со знаком вопроса в этот раздел были добавлены два экземпляра под номерами №№ 199, 200. Общий стиль оформления монетного поля и наличие в легенде оборотной стороны отдельно стоящего слога ку между второй и третьей строкой, был трактован как часть наименования монетного двора Баку. Но непрочекан описываемых экземпляров, двойной удар на одном из них (№ 199), наличие надчеканов султана Шахруха, а так же отсутствие в доступных публикациях и нумизматической литературе описания этого типа монет заставило авторов с долей сомнения отнестись к идентификации названия монетного двора. Это сомнение заставило обратиться к целенаправленному поиску и изучению этого типа монет. 
Цель данного исследования уточнение атрибуции двух экземпляров тимуридских серебряных танга, ранее опубликованных в каталоге монет Сайрамского клада, найденного в 2013 г. в ходе раскопок на территории Сайрамского района г. Шымкента. Поиск танга интересующего типа был таки обнаружен, что и позволило в точности установить выпускные сведения монет из клада.

Приведем

описаниереконструкцию монетных легенд изучаемого экземпляра (рис. $1, A$ ).

А. Махмуд хан и амир Тимур. Салмас. Танга. AR, B=5,67 г, Д=24,727,8 мм.

Л.c. В поле сложного картуша - калима и наименование монетного двора:

$$
\text { لمه]/ محمد /ضربب سلماس/ الاس رسول الله }
$$

По четырем сторонам - имена четырех халифов (основанием к внешнему ободку):

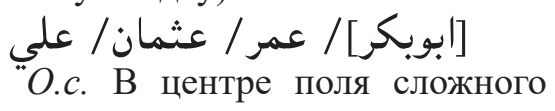
фигурного картуша - легенда:

ر تيمو[ر ركان]/ ك[و]/ خلد ال[بله ملكه]

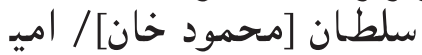

В нижнем секторе - виньетка («плетенка»).

В малых сегментах - композиция из трех точек.

В крупных сегментах - надпись: не читается.

Сравнение штемпельных оттисков фиксирует идентичность оборотных сторон опубликованных двух монет и описываемого экземпляра. Л.c. № 199 (рис. 1, 199) является одноштемпельной с Л.с. обнаруженной монеты (рис. $1, A$ ). Именно на-
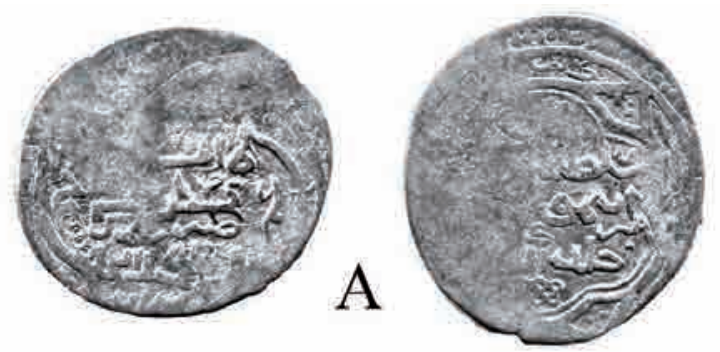
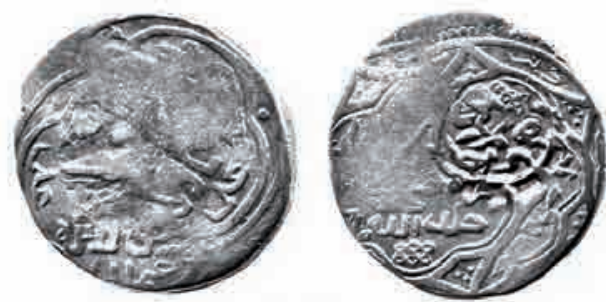

199
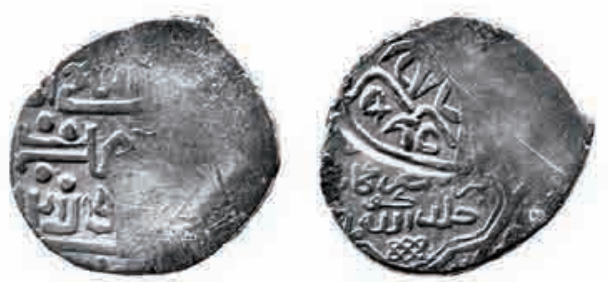

200

Рис. 1. А-Салмас, Махмуд хан и амир Тимур, танга; 199 и 200 - продукиия монетного двора Салмас из каталога монет Сайрамского клада, отнесенная к чекану Бакуйи(?)

Fig. 1. A-Salmas, Mahmoud Khan and Amir Timur, Tanga; 199 and 200 -products of the Salmas mint from the Sairam treasure coin catalog, referred to the Bakuii mintage (?) 
Брагин А.О. Переатрибуция одной из монет Сайрамского клада 2013 г.

личие названия монетного двора на монете (рис. 1) и утрата его на экземпляре № 199 позволяет нам отнести эту серию к чекану монетного двора Салмас. Монета № 200 (рис. 1, 200) имеет другой штемпель Л.с., но ее связь через штемпель О.с. с монетой (рис. $1, A)$ и экземпляром № 199 (рис. 1,199$)$ так же указывает на выпуск в Салмасе.

Хочется отметить одно немаловажное наблюдение относительно веса самих монет, которое требует дальнейшего более подробного изучения. Экземпляр № 199 весит 5,56 г, что очень близко к весу 5,67 г описываемого в данной статье. Вес монеты № 200 существенно выше и составляет 6,11 г. В разделе каталога Сайрамского клада, посвященного монетам Салмаса, приведены серебряные танга другого типа (№ $979-\mathrm{B}=5,53$ г; № $980-\mathrm{B}=5,66$ г; № $981-\mathrm{B}=5,79$ г; № 982 - В=5,63 г), но вес всех четырех экземпляров тяготеет к норме
5,72 г (мискал и 4/3 данга мискала, т.е. танга без 1/12 части). Существование монеты с пониженным значением веса может свидетельствовать о факте одновременного существования нескольких весовых норм чеканки танга или о появлении как минимум еще одного номинала непосредственно на данном монетном дворе.

Исправление неточности первичного определения монет является важным аспектом планомерной работы нумизматов по систематизации и дальнейшей обработке монетного материала, чеканенного в эпоху амира Тимура и первых Тимуридов. Проведенный анализ и поиск информации по раннему монетному чекану амира Тимура позволяет сделать вывод об актуальности поднятой темы для дальнейшего изучения монетного дела и денежного обращения при амире Тимуре и Тимуридах в конце XIV - начале XV в.

\section{ЛИТЕРАТУРА}

1. Байтанаев Б.А., Брагин А.О., Петров П.Н. Сайрамский клад тимуридских монет. Каталог: кн. 1. Алматы: Институт археологии им. А.Х. Маргулана, 2014a. $812 \mathrm{c}$.

2. Байтанаев Б.А., Брагин А.О., Петров П.Н. Сайрамский клад тимуридских монет (предварительные итоги) // Восхождение к вершинам археологии: сб. матер. Междунар. научн. конф. «Древние и средневековые государства на территории Казахстана», посвящ. 90-летию со дня рождения К.А. Акишева. Отв. ред. Б.А. Байтанаев. Алматы: Институт археологии им. А.Х. Маргулана, 2014б. С. 406-412.

3. Байтанаев Б.А., Брагин А.О., Петров П.Н. Сайрамский клад тимуридских монет. Каталог: кн. 2: Надчеканы. Алматы: Институт археологии им. А.Х. Маргулана, 2015. $372 \mathrm{c}$.

Сведения об авторе:

Брагин Андрей Олегович - аспирант, Институт истории им. Ш. Марджани Академии наук Республики Татарстан (г. Санкт-Петербург, Россия); rasmir@mail.ru

\section{САЙРАМ КӨМБЕСІНЕН 2013 ЖЫЛЫ ТАБЫЛҒАН ТИЫННЫҢ БІРІН ҚАЙТА АТРИБУЦИЯЛАУ}

\section{А.О. Брагин}

Сайрам көмбесінен 2013 жылы табылған тимуридтар кезеңімен мерзімделетін күміс тиындардың баламаларын мақсатты түрде іздеу нәтижесінде көмбедегі тиындардың бір түрінің атрибуциясын нақтылауға мүмкіндік туындап отыр. Мақалада 
ақша сарайының атауы сақталып қалған күміс теңге сипатталады, бұл өз кезегіңде «Тимурид тиындарының Сайрам көмбесі» каталогындағы 199 және 200 нөмерлерімен берілген тиын түрлеріне ұқсас. Әуелде каталог авторлары бұл екі тиынды Бакуйа ақша сарайына жатқызған болатын, бірақ та табылып отырған тиын үлгісі аталмыш атрибуцияны өзгертіп, теңгенің соғылған жері Салмас ақша сарайына жатқызуға мүмкіндік беріп отыр.

Түйін сөздер: археология, Сайрам көмбесі, нумизматика, XIV-XV ғғ., Тимуридтар, әмір Темір, каталог, тиын аңызы, ақша сарайы, теңге, күміс, атрибуцияны нақтылау

\section{NEW ATTRIBUTION ONE OF THE COINS OF THE SAIRAM'S TREASURE 2013}

\section{A.O. Bragin}

In the treasure of 2013 from Sairam there was one type of coins of Timur with the missing name of the mint. The authors attributed these coins products Bakuya. But one copy of this coin was found in a private collection in Russia. He retained the name of the mint Salmas. The study of the Metrology of the coins in Timur's time in Salmas allowed us to assume the existence of minting coins of different value.

Keywords: archaeology, Sairam treasure, numismatics, XIV-XV centuries, Timurids, Amir Timur, catalogue, coin legends, mint, Tanga, silver, specification of attribution

\section{REFERENCES}

1. Baitanayev, B. A., Bragin, A. O., Petrov, P. N. 2014a. Sairamskii klad timuridskih monet. Katalog: kn. I. (Sairam treasure of Timurid coins. Catalog: book. 1). Almaty: Archaeology Institute after Margulan A.Kh. (in Russian).

2. Baitanayev, B. A., Bragin, A. O., Petrov, P. N. 2014b. In Baitanayev, B. A. (ed.) Voskhozhdenie $k$ vershinam arheologii (Climbing to the heights of archaeology). Almaty: Archaeology Institute after Margulan A.Kh., 406-412 (in Russian).

3. Baitanayev, B. A., Bragin, A. O., Petrov, P. N. 2015. Sairamskii klad timuridskih monet. Katalog: kn. II: Nadchekany (Sairam treasure of Timurid coins. Catalog: book. 2: Achievements). Almaty: Archaeology Institute after Margulan A.Kh. (in Russian).

\footnotetext{
About the Author:

Bragin Andrey O. Post-graduate student, Sh. Marjani Institute of History, Tatarstan Academy of Sciences, Saint Petersburg, Russia; rasmir@mail.ru
} 